\title{
VERTICAL DISTRIBUTION OF ZOOPLANKTON AND PHYSICO-CHEMICAL CONDITIONS DURING A 24-HOUR PERIOD IN AN AMAZON \\ FLOODPLAIN LAKE - LAGO CALADO, BRAZIL1.
}

\author{
Thomas R. Fisher 2 \\ John M. Melack 3 \\ Barbara Robertson 4 \\ Elsa R. Hardy 4 \\ Luiz Fernando Alves 4
}

\section{Summary}

In May 1980 Lago Calado was 9 meters deep, the water level was rising slowly, and below 4 meters the water was anoxic. Virtually all of the rooplankton was in the oxygenated layer. Adult and juvenile Daphnia gessneri, the most abundant crustacean species, occurred between 0.5 and 4.5 meters. Copepod nauplii tended to occur nearer to the surface, in the 0-2 meter stratum. No clear vertical migration was observed.

The epilimnion was undersaturated ( $<40 \%$ oxygen) and contained $<0.1 \mu \mathrm{M}$ phosphate, ammonium and nitrate. The hypolimnion contained substantial phosphate $(>2 \mu \mathrm{M})$ and ammonium $(>5 \mu \mathrm{M})$, but little nitrate $(<0.1 \mu \mathrm{M})$. A peak in particulate carbon and nitrogen occurred between 4-5 meters, just below the thermocline, and was associated with a pigment maximum.

\section{INTRODUCTION}

Diel vertical migration of zooplankton is a widespread and frequent occurrence in lakes (Hutchinson, 1967). Although much less studied in tropical waters, examples of vertical migration are known from lakes in Africa (Worthington \& Ricardo, 1936, Begg, 1976), Asia (Rut- tner, 1943, Lewis, 1979) and Central and South America (Deevey et al., 1980, Zaret \& Suffern, 1976, Arcifa-Zago, 1978). A common feature to many tropical lakes is an anoxic hypolimnion (Beadle, 1974). and there are records of the zooplankton migrating in and out of these anoxic waters. (Beadle, 1963). Such movements may enable the zooplankton to feed on hypolimnetic material and avoid predators. Vertical upward fluxes of nutrients also may be enhanced by the excretion of the nitrogen and phosphorous obtained below the thermocline.

The floodplain of the Amazon basin contains hundreds of lakes, many of which present an anoxic hypolimnion for much of the year(Schmidt, 1973, Marlier, 1967,1973). The zooplankton in these lakes can be abundant and is the main food item of a number of fish species (Goulding, 1980). In this study our purpose was to determine the extent of vertical migration of the zooplankton in a lake with an anoxic hypolimnion. For aid in interpreting the zooplankton movements, we also present a physico-chemical description of the water column.

1) Financial support is provided by U.S. National Science Foundation grants DEB 78 23642 and DEB 81-11398 to TRF and JMM.

2) Horn Point Environmental Laboratory, University of Maryland, Cambridge, Maryland, U.S.A.

3) Department: of Biological Sciences and Marine Science Institute, University of California, Santa Barbara, California, U. S.A.

4) Instituto Nacional de Pesquisas da Amazônia, Manaus, Amazonas, Brazil. 


\section{STUDY AREA}

Lago Calado $\left(3^{\circ} 15^{\prime} \mathrm{S}, 60^{\circ} 34^{\prime} \mathrm{W}\right)$ is situated in the floodplain of the central Amazon basin on the left bank of the Rio Solimões, about $60 \mathrm{~km}$ upriver from its confluence with the Rio Negro. (Fig. 1). As it is connected to the Rio Solimões all year around, the lake's water level rises and falls parallel with the river's annual flood. Lago Calado is a dendritic lake with an area varying between 2 and $8 \mathrm{~km}^{2}$, and maximum depths varying between 2 and 12 meters. During this particular sampling period, the lake was about $6,5 \mathrm{~km}^{2}$ in area and 9 meter deep, and while the greater part of the lake was open water, considerable areas, particularly near the channel, were covered by aquatic macrophytes. Flooded forest fringes much of the shore. Our sampling site was situated in the middle of a large open water area (ca. $0.5 \mathrm{~km}^{2}$ ), in the southern end of the lake, approximatly $2 \mathrm{~km}$ from the channel which connects the lake to the river. The rainy season was ending, the river rising slowly, and the lake contained basically decanted river water.

Additional geographic and limnological data on Lago Calado is available in Goth (1971), Junk (1973), Reiss (1976), and Rai \& Hill (1980).

\section{METHODS}

Zooplankton samples were collected with a hand-operated diaphram pump every 2 hours for a 24-hour period (May 30-31, 1980). Twenty liters of water, collected at meter depth intervals, were filtered through a $55 \mu$ plankton net. The samples were preserved immediatly with formalin (final concentration 6\%). Samples were taken from the surface to 4 or 5 meters depending on the position of the oxycline and the presence or absence of animals at 4 meters. Two complete vertical profiles were sampled at $2200 \mathrm{~h}$ May
30 and $1000 \mathrm{~h}$ May 31 in order to verify the absence of animals in the hypolimnion.

For analyses of the zooplankton samples, two $5 \mathrm{ml}$ subsamples, taken with a Stempel pipette, were counted. All animals, except rotifers, were identified and counted with the aid of a stereomicroscope. Adult Cladocera were identified and counted separately from juvenile females. Due to the scarcity of adult material, copepods were not identified to species, but recognizable Calanoid taxa include Rhacodiaptomus calatus and Notodiaptomus spp. The copepodite stages of Calanoida and Cyclopoida were counted separately, but all nauplii were counted together. Occacional plankters such as water mites, ostracods and Chaoborus larvae were also counted.

Vertical profiles of temperature were taken with a Wheatstone bridge circuit thermistor, readable to $\mathrm{O}$. ${ }^{\circ} \mathrm{C}$. Vertical profiles of dissolved oxygen were measured with a Clark polarographic electrode equipped with a submersible stirrer (accuracy ca. $0.2 \mathrm{mg} \mathrm{1}^{-1}$ ), calibrated in air before each profile. Water samples were collected at meter intervals with a 1 liter van Dorn bottle adapted for horizontal closure. Electrical conductance and $\mathrm{pH}$ were measured with portable meters. A combination $\mathrm{pH}$ electrode, calibrated with standard buffers at $\mathrm{pH} .4$ and 7 , was used. Subsamples of water, for the dissolved inorganic nutrients analises, were either filtered immediatly through glass fiber filters (Gelman $A / E$ ), or refrigerated for posterior analisis. Nutrients were analyzed with the following methods: ammonium - indophenol blue (Koroleff, 1969), Phosphate-molybdenum blue (Strickland \& Parsons, 1972), nitrate cadmium reduction to nitrite (Strickland \& Parsons, 1972), and silicate-molybdo-silicate (Strickland \& Parsons, 1972).

Seston was collected on pre-weighed, pre-combusted glass fiber filters (Gelman $A / E)$. The filters were dried at 


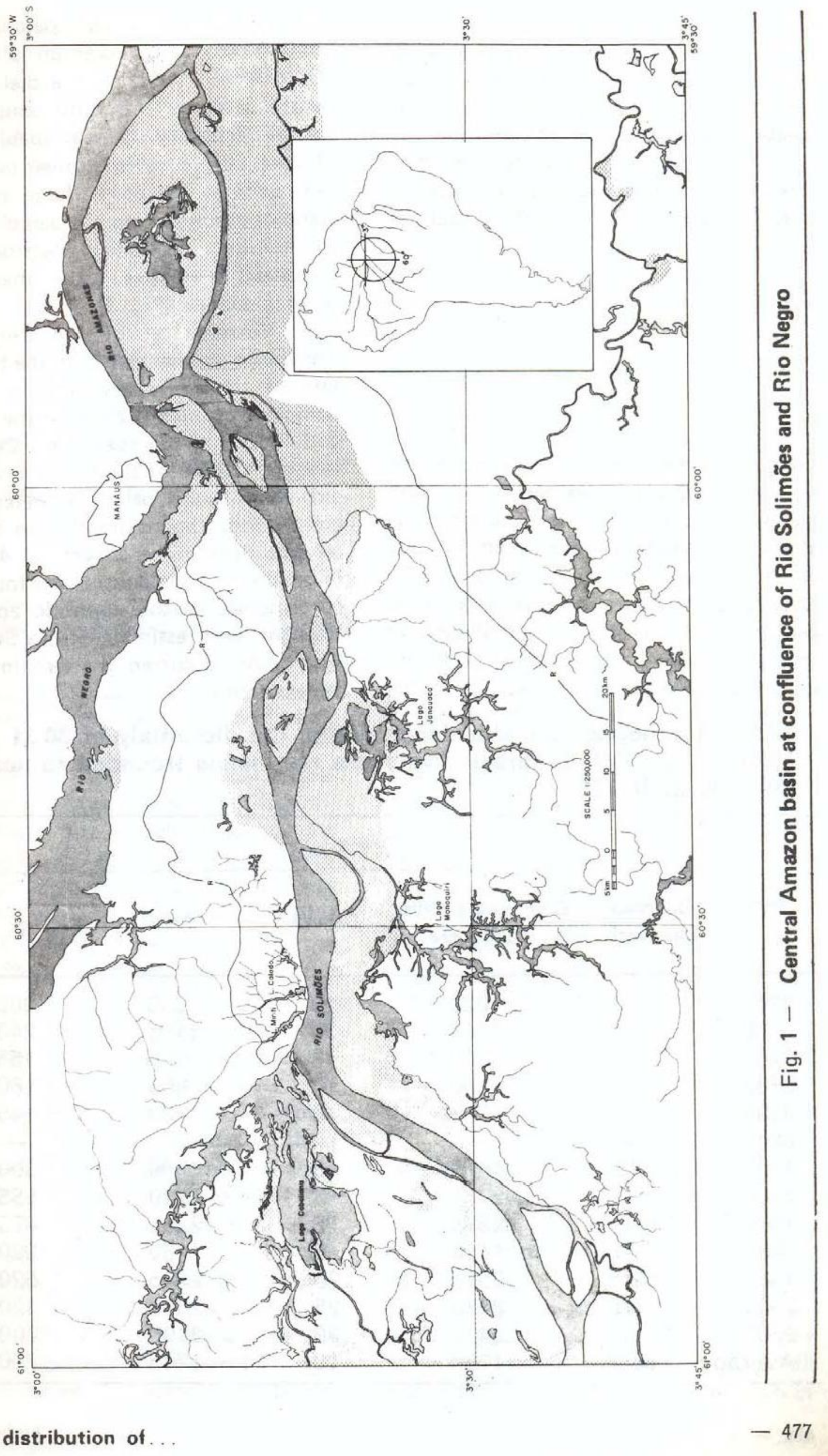


$40^{\circ} \mathrm{C}$, reweighed on a microbalance, and then combusted in a Perkin-Elmer 240B elemental analyzer, standardized with acetanilide (for determination of particulate nitrogen and organic carbon).

Pigments were analyzed as chlorophyll a by the method of Lorenzen (1967) using pre-combusted Gelman A/E glass fiber filters.

Transparency was measured using a $20 \mathrm{~cm}$, white Secchi disc.

\section{RESULTS}

The standing-stock of zooplankton sampled during the study is summarized in Table I. Daphnia gessneri was the single most abundant taxon. The standingstock increased by a factor of about three during the 24-hour period. (Fig. 2). Taking into consideration the short sampling interval, , it is unlikely that such an increase is due to reproduction. It is much more likely to be the result of spatial heterogeneity. Spatial patchiness of zooplankton is a common phenomena (Hutchinson, 1967), and a diel sampling regime often reflects both temporal and spatial variability. Most probably a patch of zooplankton drifted under our anchored position. Due to the large increase in standing-stock during the sampling interval, the data on vertical distribution are presented as relative, rather than absolute, abundances. (Fig. 3).

Virtually all of the zooplankton was found, concentrated, in the top $4 \mathrm{me}$ ters of the water columm. In the two complete profiles $(2200 \mathrm{~h}$ of the first day and $1000 \mathrm{~h}$ of the next), only Chaoborus larvae $(<0.5 \%$ of the total standing-stock) were found below 4 meters which corresponds, approximatly, to the zero oxygen depth. The superficial 4 meters, in which the zooplankton was found, also corresponds to the euphotic zone. The $1 \%$ light limit, estimated from the Secchi Disc depth, occurred at approximatly 3.1 meters depth.

TABLE 1. Zooplankton abundance during the diel study of 30-31 May, 1980 in Lago Calado, Brazil. Numbers are means (rounded to nearest multiple of five)

$10^{3} \mathrm{~m}^{-2}$

\begin{tabular}{|c|c|c|c|c|c|}
\hline \multirow[b]{2}{*}{ Time } & \multicolumn{5}{|c|}{$10^{3} \mathrm{~m}^{-2}$} \\
\hline & $\begin{array}{l}\text { Daphnia } \\
\text { gessneri }\end{array}$ & $\begin{array}{l}\text { Copepods \& Other } \\
\text { Cladocera }\end{array}$ & Others & Total & Ave. \# 1-1 \\
\hline 2200 & 360 & 1020 & 10 & 1030 & 205 \\
\hline 2400 & 270 & 1165 & 30 & 1195 & 240 \\
\hline 0200 & 195 & 760 & 3 & 765 & 155 \\
\hline 0400 & 615 & 890 & 15 & 905 & 180 \\
\hline 0600 & 225 & 730 & 0 & 730 & 145 \\
\hline 0800 & - & - & - & - & - \\
\hline 1000 & 325 & 1495 & 3 & 1500 & 300 \\
\hline 1200 & 1510 & 2775 & 3 & 2780 & 555 \\
\hline 1400 & 640 & 2375 & 5 & 2385 & 475 \\
\hline 1600 & 470 & 1450 & 3 & 1450 & 290 \\
\hline 1800 & 520 & 2575 & 20 & 2595 & 520 \\
\hline 2000 & 1160 & 2070 & 25 & 2095 & 420 \\
\hline 2200 & 2215 & 3475 & 20 & 3490 & 700 \\
\hline Average & 685 & 1730 & 10 & 1745 & 350 \\
\hline
\end{tabular}




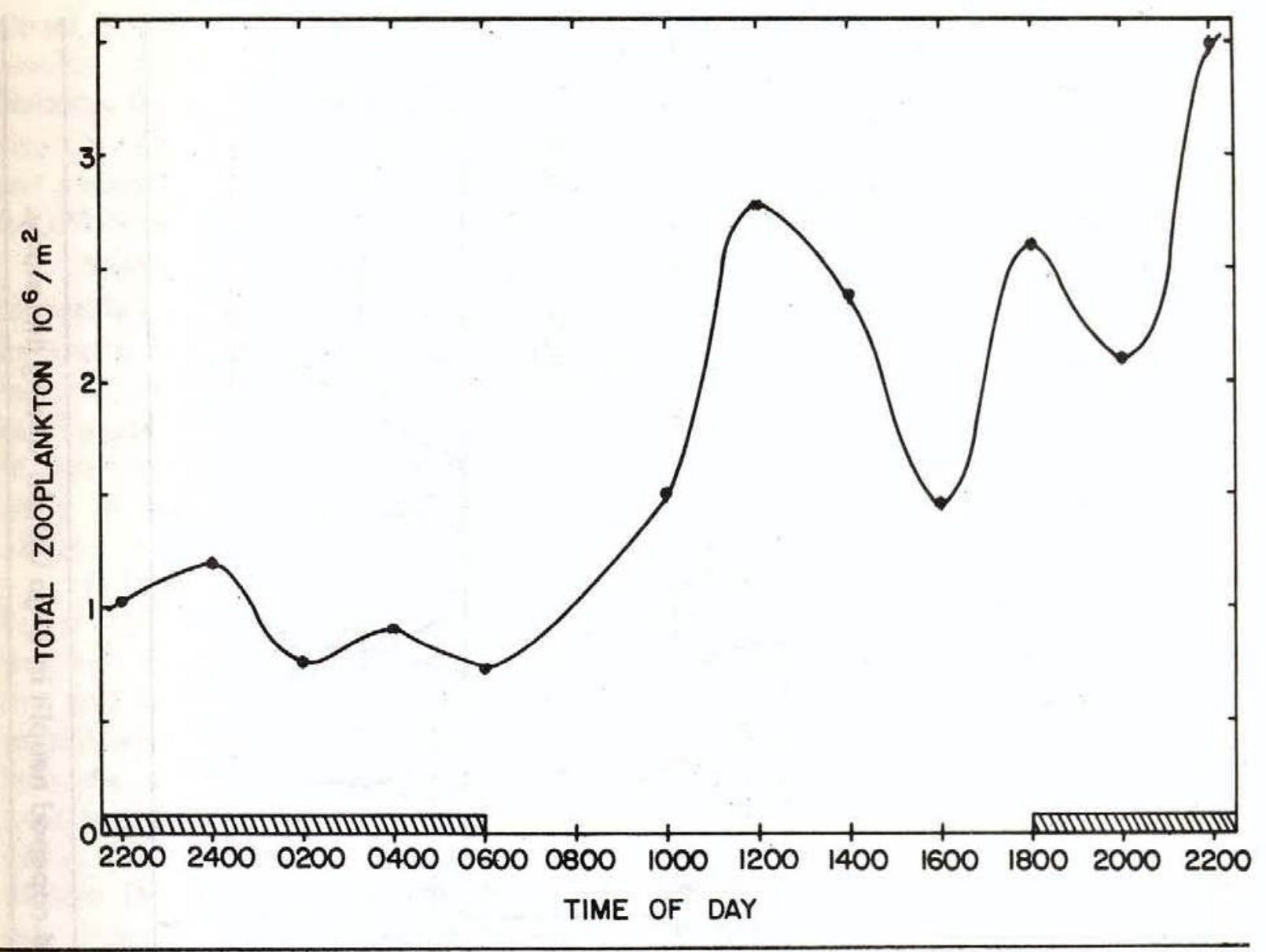

Fig. 2 - Total abundance of zooplankton in a 4 meter water column of Lago Calado.

While no clear diel vertical migration occurred, vertical movement was observed. There was a slight tendency for the animals, particularly Daphnia, to be in a lower position in the water column during the early morning hours, exibit somewhat erratic movement during the day, and move to a lower position in the evening.

Adult and juvenile D. gessneri tended to avoid the surface and were restricted to the superficial 4 meter layer, particularly between 0.5 and 4.5 meters. (Fig. 3). Adults were especially likely to be found at 2 or $3 \mathrm{~m}$ depth, whereas the juveniles tended to occupy the $1 \mathrm{me}$ ter layer. In contrast, copepod nauplii were frequently found in the surface layers, concentrated between 0 and 2 meters.

The observed diel pattern of the vertical distribution of temperature and oxygen is shown in figures 4 and 5 . Du- ring the night the epilimnion cooled, deepened, and increased in oxygen content. During the morning $(0600-1200)$ heating occured and superficial stratification developed: little change in oxygen was observed. Afternoon and evening cooling followed and again the epilimnion mixed. In general, though, throughout the 24-hour period the lake remained thermally stratified at the surface, with anoxic water below 4 meters, and oxygen concentrations undersaturated $(<40 \%)$ in the epilimnion.

The vertical profiles of $\mathrm{pH}$ and conductivity varied little during the period of study, but differences were always observed between the hypolimnion and epilimnion. (Examples of these profiles are given in Fig. 6). The upper 4 meters, as has been mentioned, was oxygenated, but undersaturated (saturation $\cong 30 \%$ ), and contained substantial silicate $(\sim 100 \mu \mathrm{M})$, but almost no phosphate, ammonium or 


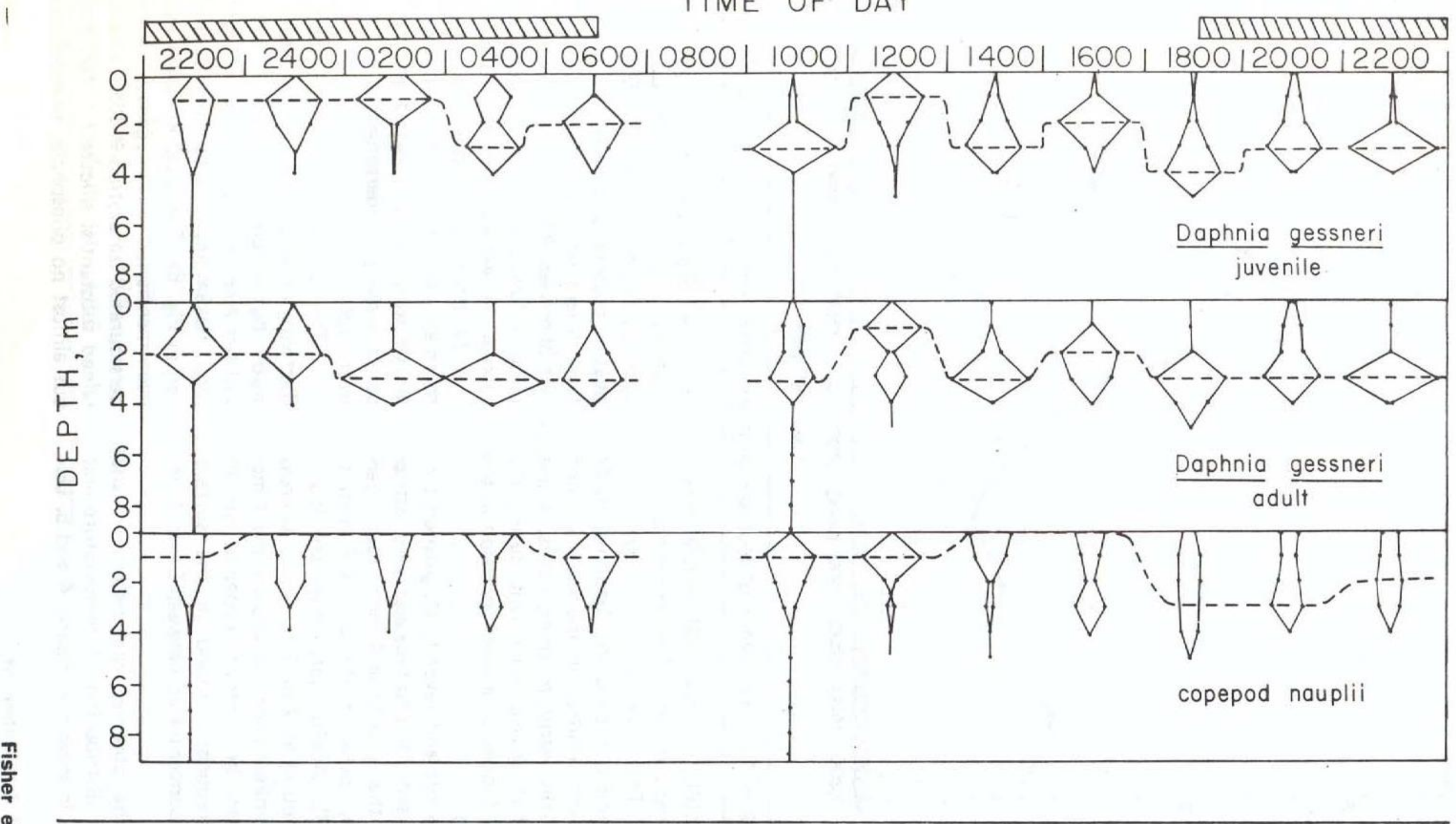


nitrate $(<0.1 \mu \mathrm{M})$. In contrast, the hypolimnion was anoxic and contained $\mathrm{H}_{2} \mathrm{~S}$ (detected by odor), large amounts of silicate $(>100 \mu \mathrm{M})$, phosphate $(>2 \mu \mathrm{M})$ and ammonium $(>5 \mu \mathrm{M})$, but less than $0.1 \mu \mathrm{M}$ nitrate.

Although there are exceptions, such as Beadle's (1963) report of rotifers and immature copepods living in the anoxic region of an equatorial lake, the avoidance of anoxic water by zooplankton is quite well known (Hutchinson, 1967), especially at warm temperatures (Ruttner, 1952).

In laboratory experiments Heisey \& Porter (1977), for example, demonstrated that two Daphnia species reduced filtering and respiration rates at oxygen concentrations below $3 \mathrm{mg} \mathrm{1-1.} \mathrm{In} \mathrm{Lago} \mathrm{Ca-}$ lado the anoxic hypolimnion also contains hydrogen sulfide, ammonium, methane, and high carbon dioxide concentrations (Melack \& Fisher, unpub). It is very likely that these reduced substances are a further deterrent to zooplankton movements. Therefore, lack of oxygen. and the presence of reducing substances are possibly the environmental cues that enable the zooplankters to avoid the hypolimnion. Positive phototaxis may also be important.

In Lago Calado confinement of the zooplankton to the epilimnion has two main ecological implications. The first concerns access to alternate food sources, and the second is related to predador avoidance.

The vertical distribution of particulate organic material in Lago Calado had two peaks in concentration, one in the upper epilimnion and one in the metalimnion. Because the upper epilimnion is the middle of the euphotic zone where maximal phytoplankton growth can be expected (Melack \& Fisher, unpub.), zooplankton in this region most probably have access to a substantial supply of food. The accumulation rate of the metalimnetic peak is not known, but this peak may exist, in part, because the zooplankton are restricted to the oxygenated water above. However, as the influence of the annual imput of nutrient-rich Rio Solimões water subsides towards the end of the rainy season (April -- June), the store of organic matter in the metalimnion would seem increasingly significant as a potential food source for the zooplankton. Unless the zooplankters modify their behaviour from that observed in May, they will not exploit the metalimnion when it is anoxic. Besides reducing the availability of food for the zooplankton, this behaviour reduces the vertical flux and regeneration of nutrients and may limit the lake's primary productivity during high and falling water levels. At this time imput of new nutrients via river is cutoff, and recycling is essentiait to maintain productivity, especially from the reservoir of nitrogen and phosphorus trapped below the thermocline. The vertical profiles of particulates showed at $1000 \mathrm{~h}$ a peak in the epilimnion, and peaks between 4 and 5 meters at both sampling times. Recent investigations using thin layer chromatography of the apparent peak of chlorophyll a at $4 \mathrm{~m}$ have shown that the pigments there are largely detrital, and that chlorophyll a has been overestimated. This is the subject of continuing research.

\section{DISCUSSION}

The distribution of the zooplankton observed in Lago Calado raises two general questions. First, how common are these restricted movements in lakes of the Amazon basin, and what environmental cues influence this behaviour? Second, what are the ecological implications of the confinement of the zooplankton to the shallow, illuminated epilimnion?

Unfortunately, additional information on the vertical migration of zooplankton from other Amazon lakes is not 
TEMPERATURE, ${ }^{\circ} \mathrm{C}$

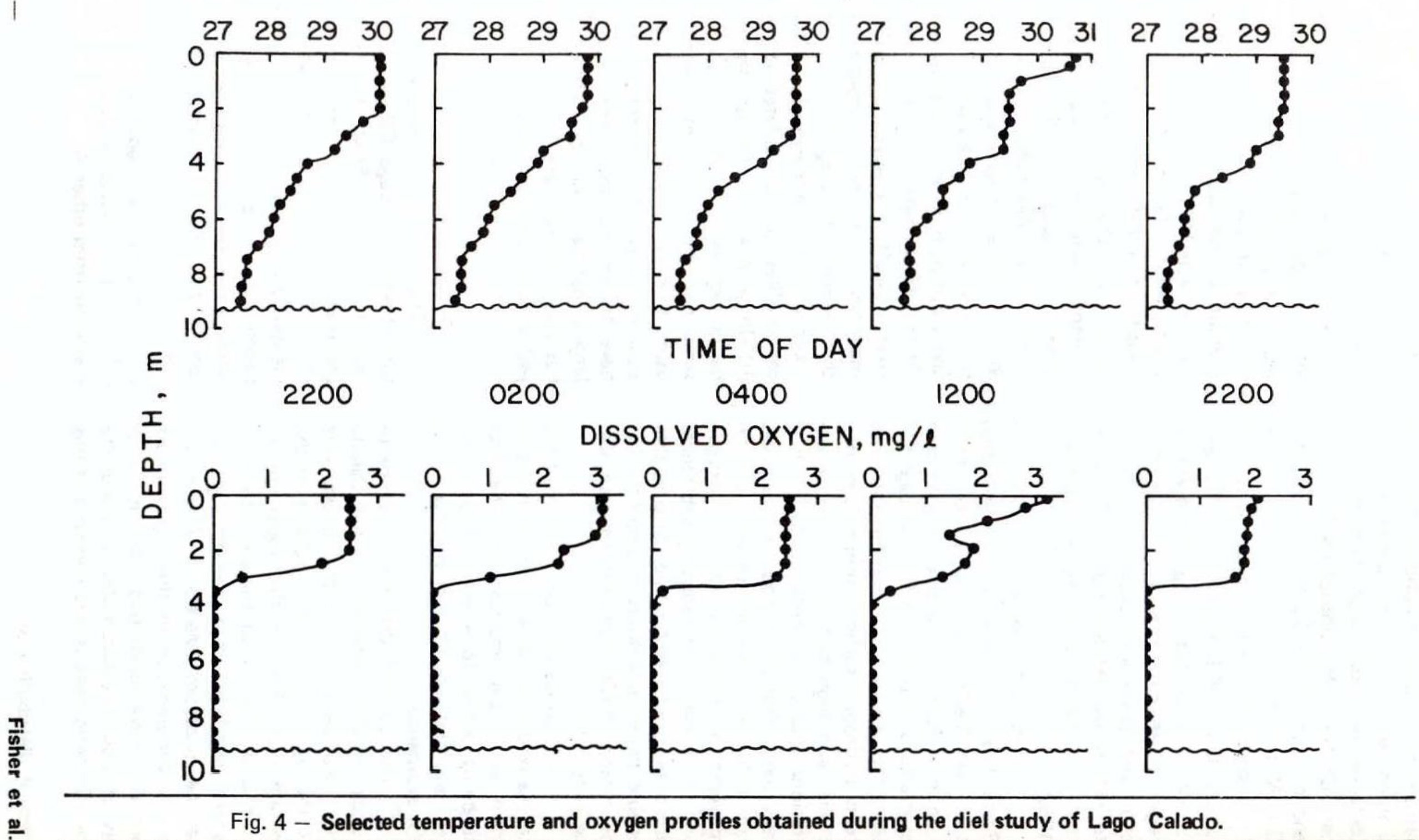




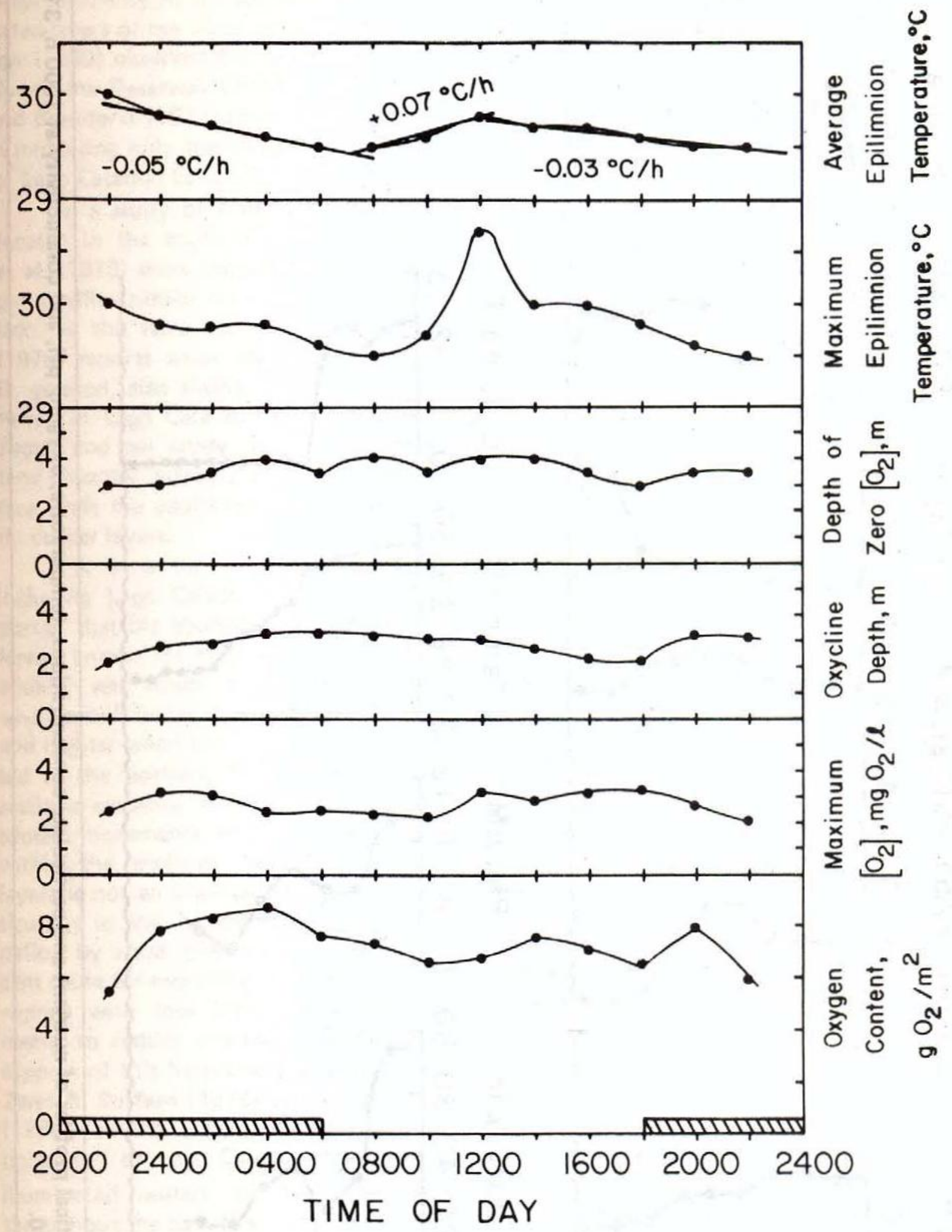

Fig. 5-Characteristics of the temperature and oxygen profiles obtained during the diel study of Lago Calado. 


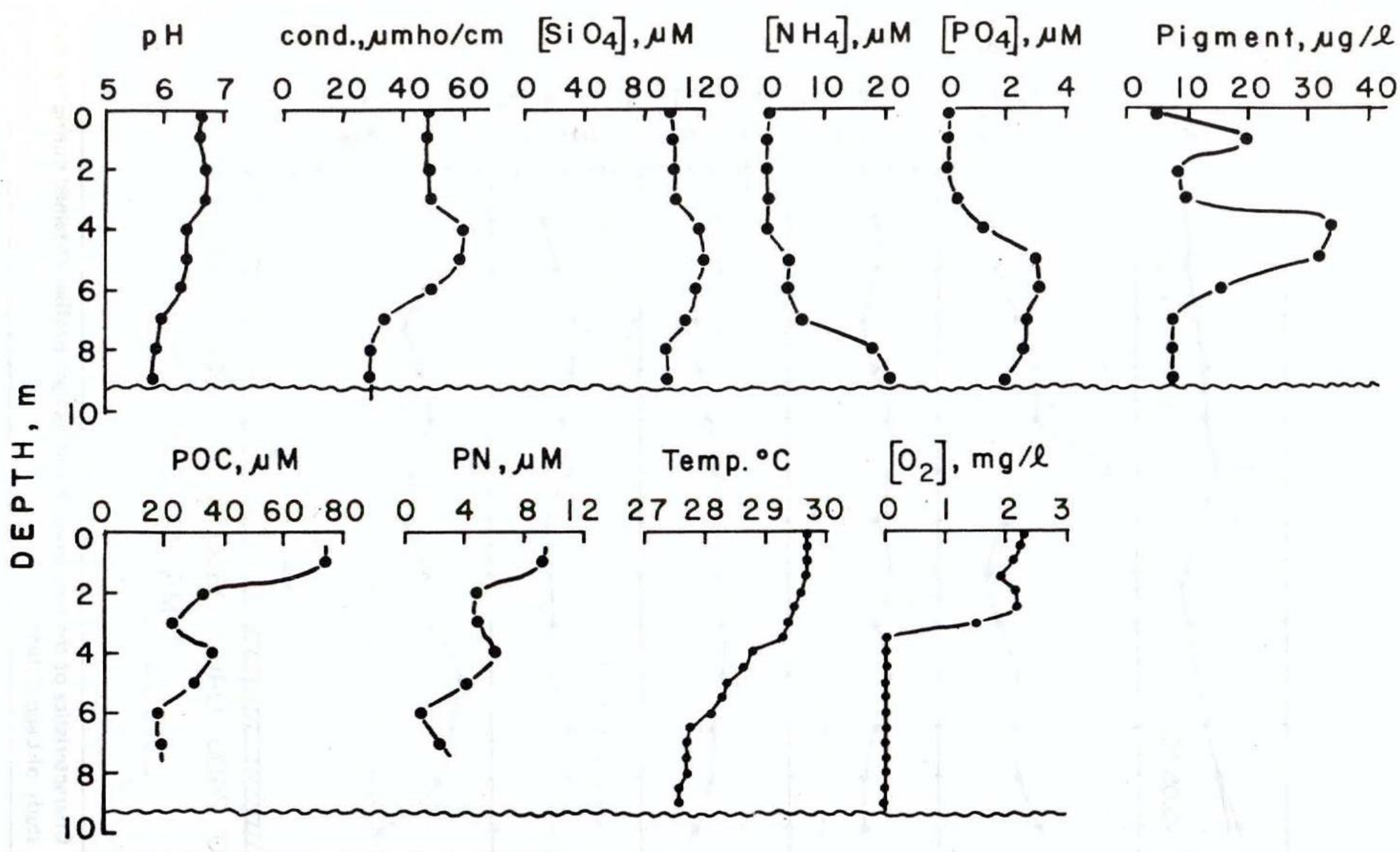

Fig. 6 - Vertical profiles of nutrient and particulate concentrations, temperature, oxygen, pH, and conductivity at $1000 \mathrm{~h}, 31 \mathrm{May}$, 1980. 
available. However, data on the vertical distribution show that the zooplankton occur primarily in the superficial, oxygenated layers of the water column. Robertson (1980) observed this situation in the Curuá-Una Reservoir (2048'S, 54019'W), and Brandorff (1977) observed D. gessneri inhabiting only the oxygenated regions of Lago Catanho (3024'S, 60014'W).

In a study of Americana Reservoir located in the south of Brazil, Froelich. et al. (1978) show temperature and oxygen profiles similar to those of Lago Calado. In the same reservoir Arcifa-Zago (1978) reports weak diel movements of D. gessneri, also similar to what was observed in Lago Calado. In both Arcifa Zago's and our study, young D. gessneri tend to occur within 2 meters of the surface while the adults concentrate in slightly deeper layers.

For a number of floodplain lakes, including Lago Calado, Reiss (1976) reported that the abundance of Chaoborus larvae, known for their ability to tolerate anoxia, was lower during the periods when anoxic water overlaid the sediments and highter when the lakes vere oxygenated to the bottom. Thus, based on the available evidence, it appears that the restricted movements of the zooplankton within the shallow, oxygenated upper layers is not an unusual phenomena, particularly in the Amazonian lakes. If predation by visual planktivores is a significant cause for mortality, diel migration to regions with low light intensities is a means to reduce mortality. Evidence in support of this hypothesis is provided by Zaret \& Suffern (1976) and Wright et al (1980), among others. Because the zooplankters of Lago Calado remain in the illuminated waters of the epilimnion throughout the day, they may be exposed to considerable predation by planktivorous fish. In late Miay an abundance of planktivorous fish larvae can be expected in the floodplain lakes due to previous spawning and flooding of river water into the lake (Brandorff \&\& Andrade 1978, Goulding, 1980). Unfortunately, we lack fish collections from Lago Calado specifically to verify the importance of predation by fishes.

\section{ACKNOWLEDGMENTS}

We thank Dr. Eneas Salati, former director of INPA and Ozorio Fonseca for guidance and support. We appreciate laboratory space and advice provided by Antonio dos Santos and the assistance of Antonio Adalberto, Manuel de Soto, Mirian Leal Carvalho and Debbie McClain. The manuscript was critically read by Lance Lesack and Scott Cooper.

\section{Resumo}

Em maio de 1980 o lago Calado apresentava uma profundidade de 9 metros e, abaixo dos 4 metros, condições anóxicas. Todo o zooplåncton se encontrava na camada oxigenada. Adultos e jovens de Daphnia gessneri, a espécie mais abundante, ocorreram entre 0.5 - 4.5 metros. Nauplius de copepoda ocorreram mais perto da superfície entre $0-2$ metros. Não houve uma migração vertical evidente. No epilimnion, o oxigênio apresentava baixos valores de saturação $(<40 \%)$, e fosfato, amônia e nitrato concentrações de $<0.1 \mu \mathrm{M}$. No hipolimnion observou-se maiores concentrações de fosfato $(>2 \mu \mathrm{M})$ e amônia ( $>5 \mu \mathrm{M}$ ), mas pouco nitrato $(<0.1 \mu \mathrm{M})$. Um pico de carbono e nitrogênio particulado ocorreu entre 4-5 metros, abaixo da termoclina, associado à um máximo de pigmento.

\section{Literature}

Arcifa-Zago, M.S. - 1978. Vertical migration of Daphnia gessneri Herbst (1967) in Americana Reservoir, State of São Paulo, Brazil. Verh. Internat. Verein. Limnol., 20: 17201726.

Beadle, L. C. 1963. Anaerobic life in a tropical crater lake. Nature, 200: 1223-1224.

- - -1974 . The inland waters of tropical Africa. London, Longman. 365 p. 
Begg, G. W. - 1976. The relationship between the diurnal movements of some zooplankton and the sardine Limnothrissa miodon in Lake Kariba, Rhodesia. Limnol. Oceanogr, 21: 529-539.

Brandorff, G-0. - 1977. (Üntersuchungen zur Populationsdynamik des Crustaceenplanktons im tropischen Lago Castanho (Amazonas, Brasilien). Ph. D. Thesis,. Univ. Kiel. 108p.

Brandorff, G-0. \& Andrade, E. R. de - 1978. The relationship between the water level of the Amazon River and the fate of the zooplankton population in Lago Jacaretinga, a varzea lake in the Central Amazon. Studies on Neotropical Fauna and Environment, 13: 63-70.

Deevey, E. S. Jr.; Deevey, G. B.; Brenner, M. 1980. Structure of zooplankton communities in the Peten lake district, Guatemala. In: Kerfoot, W. C. ed. - Evolution and ecology of zooplankton communities. New England, Univ. Press. p.669-678.

Froehlich, C.G.; Arcifa-Zago, M.S.; Juliano de Carvalho, M.A. - 1978. Temperature and oxygen stratification in American Reservoir, State of São Paulo, Brasil. Verh. Internat. Verein. Limnol., 20: 1710-1719.

Goth, V. P. - 1971. Untersuchungen "uber einige Spurenelemente in Seen. Arch. Hydrobiol., 68: 305-375.

Goulding, M. - 1980. The fishes and the forest. Los Angeles, Univ. of California. 280p.

Heisey, D. \& Porter, K. G. - 1977. The effect of ambient oxygen concentrations on filtering and respiration rates of Daphnia galeata mendotae and Daphnia magna. Limnol. Oceanorgr., 22: 839-845.

Hutchinson, G. E. - 1967. A treatise on limnology. New York, John Wiley. v. 2, 1115p

Junk, W. J. - 1970. Investigations on the ecology and production-biology of the "floating meadows" (Paspalo-Echinochloetum) on the middle Amazon. I. The floating vegetation and its ecology. Amazoniana, 2: 449-495.

1973. Investigations on the ecology and production-biology of the "floating meadows" (Paspalo-Echinochloetum) on the middle Amazon. II. The aquatic fauna in the root zone of the floating vegetation. Amazoniana, 4:9-102.
Koroleff, F. - 1969. Direct determination of ammonia as indophenol blue. Int. Con. Explor. Mar. C.M., C: 9

Lewis Jr., W. M. - 1979. Zooplankton community analysis. New York, Springer-Verlag. 163p.

Lorenzen, C. J. - 1967. Determination of chlorophyll and pheo-pigments: spectrophotometric equations. Limnol. Oceanogr., 12: 343-346.

Marlier, G. - 1967. Ecological studies of some lakes of the Amazon Valley. Amazoniana, $1(2): 91-115$.

---- 1973. Limnology of the Congo and Amazon River. In: Meggers, B. J.; Ayensu, E. S.; Duckworth, W. D. eds. - Tropical forest Ecosystemes in Africa and South America: a comprehensive review. Washington, Smithsonian Institution. p. 223-238.

Rai, H. \& Hill, G. - 1980. Classification of Central Amazon lakes on the basis of their microbiological and physico-chemical characteristics. Hydrobiologia, 72: 85-99.

Reiss, F. - 1976. Charkterisierung Zentralamazonischer Seen aufgrund ihrer Makrobenthos ., fauna. Amazoniana, 6: 123-134.

Robertson, B. A. - 1980. Composição, abundância $\theta$ distribuição de Cladocera (Crustacea) na região de água livre da Represa de Curua-Una, Para. M. Sc. thesis, FUA/INPA/ CNPq. 105p.

Ruttner, F. - 1943. Beobachtungen über die tägliche Vertikalwanderungdes Planktons in tropischen Seen. Arch. Hydrobiol., 40: 474-492.

----- 1952. Plankton Studien der Deuts. chen Limnologischen Sunda Expedition. Arch. Hydrobiol., 21 : 1-274.

Schmidt, G. W. - 1973. Primary production of phytoplankton in three types of Amazonian waters. II. The limnology of a tropical floodplain lake in Central Amazonia (Lago Castanho). Amazoniana, 4: 139-203

Strickland, J. D. \& Parsons, T. R. - 1972. A practical handbook of seawater analysis. 2 ed. Bull. Fish. Res. Bd. Canada, 167.

Worthington, E. B. \& Ricardo, C. K. - 1936. Scientific results of the Cambridge Expe- 
dition to the East African lakes 1930-31. No. 17. The vertical distribution and movements of the plankton in Lakes Rufolf, Naivasha, Edward and Buyoni. J. Limn. Soc. Zool., 40: 33-69.

Wright, D.; O'Brien, W. J.; Vinyard, G. L. 1980. Adaptive value of vertical migration: a simulation model argument for the predation hypothesis. In: Kerfoot, W. C. ed.-
Evolution and ecology of zooplankton communities. New England, Univ. Press of N. E. p. 138-147.

Zaret, T. M. \& Suffern, J. S. - 1976. Vertical migration in zooplankton as a predator avoidance mecanism. Limnol. Oceanogr., 21: 804-813.

(Aceito para publicação em 7/9/83) 